\title{
In Vivo and In Vitro Evaluation of the Efficacy of a Peracetic Acid-Based Disinfectant for Decontamination of Acrylic Resins
}

\author{
Ana Lúcia Campani CHASSOT ${ }^{1}$ \\ Maria Inês Pereira POISL ${ }^{2}$ \\ Susana Maria Werner SAMUEL ${ }^{3}$

\begin{abstract}
${ }^{1}$ Department of Nursing and Dentistry, Faculty of Dentistry, University of Santa Cruz do Sul, Santa Cruz do Sul, RS, Brazil

${ }^{2}$ Department of Microbiology, Institute of Basic Health Sciences and ${ }^{3}$ Department of Conservative Dentistry, Faculty of Dentistry, Federal University of Rio Grande do Sul, Porto Alegre, RS, Brazil
\end{abstract}

\begin{abstract}
The purpose of this study was to assess the antimicrobial efficacy of a peracetic acid-based disinfectant for decontamination of heatpolymerized, chemically activated and microwave-polymerized acrylic resins. Resin plates were contaminated in vivo upon intraoral use by 10 volunteers for 7 nights and slabs were contaminated in vitro by contact with Bacillus subtilis and Bacillus stearothermophilus. The contaminated acrylic resin specimens were immersed in a $0.2 \%$ peracetic acid-based disinfectant (Sterilife ${ }^{\circledR}$; Lifemed) for 5 min or $10 \mathrm{~min}$ and placed in a BHI culture medium. After incubation at $37^{\circ} \mathrm{C}$ for $48 \mathrm{~h}$, bacterial growth was assessed by analyzing turbidity of the medium. For all types of acrylic resin, no turbidity of the medium was observed for any of the resin specimens immersed in the peracetic acid-based disinfectant for either 5 or $10 \mathrm{~min}$. On the other hand, the media with specimens that were not immersed in the disinfectant (control) showed turbidity in $100 \%$ of the cases, indicating the presence of microorganisms in both tested conditions. In conclusion, immersion for at least $5 \mathrm{~min}$ in a $0.2 \%$ peracetic acid-based disinfectant promoted high-level disinfection of heatpolymerized, chemically activated and microwave-polymerized acrylic resins contaminated with either human saliva or Bacillus subtilis or Bacillus stearothermophilus.
\end{abstract}

Key Words: disinfection, peracetic acid, acrylic resin.

\section{INTRODUCTION}

Dental practice involves several risks of contamination due to the frequent contact with blood and saliva. Extracorporeal survival of microorganisms may range from a few minutes to a few weeks, and infectious diseases such as syphilis, gonorrhea, tuberculosis, diphtheria, measles, viral parotiditis, rubella, influenza, herpes, varicella, cytomegalovirus infection, viral hepatitis and acquired human immunodeficiency syndrome, may be transmitted during dental treatment.

In view of this, compliance with universal biosecurity policies, such as the adoption of strict disinfection measures, is of paramount importance to prevent interpatient microbiological cross-contamina- tion within the dental office and laboratory. All impressions, cast models and prostheses should be properly disinfected before being sent to the prosthetic laboratory as well as when they are sent back to the dental office before placement in the patient's mouth. Impression materials are invariably contaminated by saliva, dental plaque or occasionally blood and cast models obtained from non-disinfected impressions also become contaminated (1). Since acrylic resin dentures are constructed on cast models, they are expected to be contaminated as well.

Acrylic resin items are considered semi-critical articles because they get in contact with the patient's healthy mucosa and must be submitted to high level disinfection or sterilization. However, as acrylic resins

Correspondence: Profa. Dra. Susana Maria Werner Samuel, Departamento de Odontologia Conservadora, Faculdade de Odontologia, UFRGS, Rua Ramiro Barcelos 2492, 90035-003 Porto Alegre, RS, Brasil. Tel/Fax: +55-51-3316-5197. e-mail: samuelsp@adufrgs.ufrgs.br 
are thermosensitive materials and should not undergo any disinfection procedure involving high temperatures, it is necessary to use chemical disinfectants.

Acrylic resins have liquid sorption capacity, which is rendered easier by the high internal energy and polarity of carboxylic groups in resin (2). Due to this property, acrylic resin dentures placed into the patient's mouth absorb saliva, which is known to be contaminated, as well as dentures immersed in chemical disinfectants might absorb these agents. Therefore, chemical disinfectants used for denture disinfection should be securely nontoxic agents because of the risk that product residues are released into the oral environment when the prostheses are back into use.

Although 1\% sodium hypochlorite and 2\% glutaraldehyde have been widely recommended for disinfection of acrylic resin items, these chemical agents are not the ideal for this purpose. Sodium hypochlorite is a bleaching agent and may interfere with the esthetics of the prostheses. Glutaraldehyde releases toxic vapors, irritants and allergens, which cause eye, nose and throat irritation, allergy, contact dermatitis, asthma and rhinitis (3). In addition, it should be used in well-ventilated places and requires the use of masks, gloves and eyeglasses. Items immersed in glutaraldehyde, especially those fabricated from porous materials like acrylic resins, must be well thoroughly washed in running water to avoid the release of toxic product residues (2).

Peracetic acid-based disinfectants have been used in food industry and water and sewerage treatment companies, as well as for decontamination and sterilization of thermosensitive medical and hospital equipment and devices. It has been considered an effective and safe alternative to glutaraldehyde by international reference institutions such as the US Food and Drug Administration (FDA), Centers for Disease Control and Prevention (CDC) and the Association for Professionals in Infection Control and Epidemiology (APIC). Peracetic acid works fast and is effective against bacteria, fungi, viruses and spores. Unlike most chemical disinfectants, peracetic acid-based disinfectants are not inactivated in the presence of organic matter. Furthermore, peracetic acid does not leave residues and does not produce harmful byproducts because its mechanism of action involves release of free oxygen and hydroxyl radicals decomposing in oxygen, water and acetic acid. Peracetic acid acts by oxidating the SS- and SH-bonds of the cell membrane, cytoplasmatic content and genetic material, oxi- dizing enzymes essential to chemical reactions for cell survival and reproduction $(4,5)$. Peracetic acid is a peroxidate that acts rapidly against all microorganisms even at low concentrations.

Sterilife ${ }^{\circledR}$ peracetic acid-based disinfectant (Lifemed Produtos Médicos Comércio Ltda, São Paulo, SP, Brazil) was introduced to the market in 1998 and has been indicated for high-level disinfection and sterilization of critical and semi-critical articles.

Considering that are thermosensitive and porous materials and the need for disinfection of acrylic resins dentures, the purpose of this study was to evaluate the antimicrobial efficacy of Sterilife ${ }^{\circledR}$ peracetic acid-based disinfectant for decontamination of acrylic resins.

\section{MATERIAL AND METHODS}

\section{In Vivo Experiment}

Thirty intraoral plates were fabricated from 3 types of acrylic resins $(n=10)$ : a heat-polymerized (Clássico; Clássico Artigos Odontológicos Ltda, São Paulo, SP, Brazil), a chemically activated (Jet; Clássico Artigos Odontológicos Ltda) and a microwave-polymerized (Ondacryl; Clássico Artigos Odontológicos Ltda). According to ISO 1567:2001 standard specifications (6), these resins are classified type 1 , type 2 and type 5 , respectively.

The acrylic resin intraoral plates were worn by 10 dental students of the Faculty of Dentistry of the Federal University of Rio Grande do Sul (UFRGS). Each volunteer used an intraoral plate of each type of resin.

For specimen preparation, irreversible hydrocolloid impressions (Jeltrate alginate impression material; Dentsply/Caulk, Milford DE, USA) of the maxillary arch of each volunteer were taken and poured with type III hard plaster (Empresa e Indústria Gesso Mossoró SA, Rio de Janeiro, RJ, Brazil). First molar and canine clasps were prepared using $0.5 \mathrm{~mm}$ orthodontic wire (Dental Morelli, São Paulo, SP, Brazil) and each cast model was used for fabrication of 10 intraoral plates of each type of acrylic resin, making up a total of 30 plates.

The volunteers were first given the chemically activated acrylic resin plates and were instructed to wear the plates for 7 consecutive nights. After every night period of use, the plates were washed in running water and stored individually in closed plastic recipients 
during the day. It was strongly advised that the plates were not supposed to be brushed or cleaned or disinfected with toothpaste or any disinfecting solution. The participants received the chemically activated and microwave-polymerized acrylic resin plates subsequently.

After the period of use, the plates were sectioned with tungsten carbide disks and 6 acrylic resin squared fragments of approximately $1 \mathrm{~cm}$ on each side were obtained from each plate. A total of 180 specimens were obtained, i.e., 60 fragments of each type of acrylic resin.

For each type of resin $(n=60), 40$ fragments were immersed in a $0.2 \%$ peracetic acid-based disinfectant $\left(\right.$ Sterilife $\left.{ }^{\circledR}\right)$, half of specimens $(\mathrm{n}=20)$ for 5 min and half of specimens $(n=20)$ for $10 \mathrm{~min}$, washed in sterile distilled water and placed in individual test tubes containing $5 \mathrm{~mL}$ of Brain Heart Infusion (BHI) culture medium. All procedures were performed close to a Bunsen burner flame under aseptic conditions. To assess the growth of aerobes, 10 test tubes containing 5-min immersion specimens and 10 test tubes containing 10 -min immersion specimens were placed at $37^{\circ} \mathrm{C}$ for $48 \mathrm{~h}$. To assess the growth of anaerobes, 10 test tubes containing 5-min immersion specimens and 10 test tubes containing 10-min immersion specimens were placed in an anaerobiosis jar, inside which there was a CO2-releasing disk (Anaerobac; Probac do Brasil Produtos Bacteriológicos Ltda., São Paulo, SP, Brazil) to produce an anaerobic environment. The jar was placed in an oven at $37^{\circ} \mathrm{C}$ for 1 week.

The remaining 20 fragments (out of 60) were used as controls and were placed in individual test tubes containing $5 \mathrm{~mL}$ of BHI culture medium.

Bacterial growth was observed by analyzing the turbidity of the culture medium after incubation.

\section{In Vitro Experiment}

The antimicrobial efficacy of the peracetic acidbased disinfectant was also assessed against known microorganisms used to control oven and autoclave effectiveness: Bacillus subtilis and Baclilus stearothermophilus, respectively. Thirty-six specimens (10 mm X $10 \mathrm{~mm}$ X $4 \mathrm{~mm}$ ) were fabricated, being 12 of each type of acrylic resin. Bacillus subtilis and Bacillus stearothermophilus were seeded in two separate test tubes containing $10 \mathrm{~mL}$ of BHI culture medium, which were incubated at $37^{\circ} \mathrm{C}$ for $48 \mathrm{~h}$.

Thereafter, the broths were poured, separately, onto sterile glass plates. Six specimens of each type of acrylic resin were immersed in the broth containing Bacillus subtilis $(\mathrm{n}=18)$ and the other 6 specimens of each type of acrylic resin were immersed in the broth containing Bacillus stearothermophilus ( $\mathrm{n}=18)$.

Of the 12 contaminated specimens of each type of resin, 8 were immersed in the peracetic acid-based disinfectant (Sterilife ${ }^{\circledR}$ ), half for 5 min and half for 10 min, and were placed in test tubes containing BHI culture medium at $37^{\circ} \mathrm{C}$ for $48 \mathrm{~h}$. Four specimens (out of the 12) served as controls (non-disinfected). They were taken from the broth containing the microorganisms (Bacillus subtilis and Bacillus stearothermophilus) with the aid of sterile tweezers and were placed directly into test tubes containing $10 \mathrm{~mL}$ of BHI. Bacterial growth was observed by analyzing the turbidity of the culture medium after the incubation period.

\section{RESULTS}

\section{In Vivo Experiment}

For all types of acrylic resin (heat-polymerized, chemically activated and microwave-polymerized), no turbidity of the BHI culture medium was observed for any of the resin specimens immersed in the peracetic acid-based disinfectant for either 5 or $10 \mathrm{~min}$, which indicates absence of bacterial growth in both aerobiosis and anaerobiosis conditions.

On the other hand, the media with specimens that were not immersed in the disinfectant (control) showed turbidity in $100 \%$ of the cases, indicating the presence of microorganisms in both aerobiosis and anaerobiosis conditions.

\section{In Vitro Experiment}

For all types of acrylic resin (heat-polymerized, chemically activated and microwave-polymerized), no turbidity of the BHI culture medium was observed for any of the resin specimens contaminated with either Bacillus subtilis or Bacillus stearothermophilus after immersion in the peracetic acid-based disinfectant for either 5 or $10 \mathrm{~min}$.

On the other hand, BHI culture media containing contaminated specimens that were not immersed in the disinfectant (control) showed turbidity in $100 \%$ of the cases, which indicates microbial contamination. 


\section{DISCUSSION}

There are several of contamination during dental practice. Therefore, measures for minimizing the possibilities of infection transmission should be taken. Dentures are sources of contamination and should be properly disinfected before being placed into the patients' mouth.

The findings of this study showed acrylic resin contamination after contact with saliva or known microorganisms, since all control specimens cause post-incubation turbidity of the culture medium. Therefore, decontamination of acrylic resin dentures and other items before sending to the laboratory is mandatory to avoid contamination of dental prosthetic technicians and their assistants. Likewise, all items sent back from the dental laboratory should be properly disinfected before being placed into the patients' mouth to protect them from cross-contamination.

Peracetic acid-based disinfectants seem to be a good option for disinfection of acrylic resins because, in addition to being effective against aerobic and anaerobic microorganisms present in contaminated acrylic resin pieces, it is a safe material for the patient, operator and environment. This is a non-toxic material, is not allergenic at low concentrations and does not have residual adverse effects. The final products of peracetic acid decomposition are water, oxygen and carbon dioxide, which are biocompatible products present in nature. Peracetic acid has been used in Medicine for disinfection of thermosensitive devices, such as endoscopes $(4,5)$.

Bacillus subtilis and Bacillus stearothermophilus were chosen to assess the antimicrobial efficacy of the peracetic acid-based disinfectant because these microorganisms are routinely used as controls to test the sterilizing capacity of ovens and autoclaves, respectively. If an agent, whether it is physical or chemical, is able to kill these pathogens, it can destroy any other microorganism under the same temperature and time conditions (7).

Although the manufacturer of the peracetic acidbased disinfectant used in the study (Sterilife ${ }^{\circledR}$ ) recommends $10 \mathrm{~min}$ of immersion for high-level disinfection and $1 \mathrm{~h}$ for sterilization, a 5-min immersion was also investigated because there are reports on the use of this shorter time for disinfection (4). Both immersion times were tested to find out the minimum time required to promote disinfection. The findings of this study showed that a 5 min of immersion in Sterilife ${ }^{\circledR}$ were sufficient to yield decontamination of the tested acrylic resins.

Because acrylic resin dentures are considered semi-critical articles, they should undergo high-level disinfection or sterilization (8). The results of this study showed that the peracetic acid-based disinfectant promoted not only disinfection but also sterilization of the acrylic resin specimens because it completely eliminated both test sporulated microorganisms (Bacillus subtilis and Bacillus stearothermophilus).

The outcomes of this study confirms the efficacy of peracetic acid as shown in previous studies $(3,5)$. It is expected that the systematic use of peracetic acidbased disinfectants for deontamination of acrylic resin items widely used in Dentistry may possibly contribute to improve infection control and minimize the risk of cross-contaminations. Further studies should evaluate the effect of this disinfectant on the properties of acrylic resins in such a way that infection control policies can be established to ensure biosecurity.

In conclusion, immersion for at least $5 \mathrm{~min}$ in a $0.2 \%$ peracetic acid-based disinfectant promoted highlevel disinfection of heat-polymerized, chemically activated and microwave-polymerized acrylic resins contaminated with either human saliva or Bacillus subtilis or Bacillus stearothermophilus.

\section{RESUMO}

O objetivo deste trabalho foi avaliar a eficácia antimicrobiológica de um desinfetante à base de ácido peracético na descontaminação de resinas acrílicas termicamente ativada, quimicamente ativada e polimerizada em forno de microondas. Placas de resina foram contaminadas in vivo por meio do uso intraoral por 10 voluntários durante 7 noites e corpos-de-prova de resina foram contaminados in vitro por meio do contato com microrganismos conhecidos: Bacillus subtilis e Bacillus stearothermophilus. Os espécimes contaminados foram imersos em desinfetante à base de ácido peracético a $0,2 \%$ (Sterilife ${ }^{\circledR}$; Lifemed) durante 5 ou 10 min e então colocados no meio de cultura BHI. Após incubação a $37^{\circ} \mathrm{C}$ for 48 h, o crescimento bacteriano foi avaliado por meio análise da turvação do meio de cultura. Todos os espécimes imersos em ácido peracético por 5 ou 10 min não apresentaram turvação do meio de cultura, enquanto os espécimes contaminados e colocados diretamente no meio de cultura (grupo controle) apresentaram turvação. Concluiu-se que a imersão em ácido peracético por pelo menos 5 min foi eficaz na desinfecção de resinas acrílicas termicamente ativada, quimicamente ativada e polimerizada em forno de microondas contaminadas tanto com saliva humana quanto com Bacillus subtilis ou Bacillus stearothermophilus. 


\section{REFERENCES}

1. Leung RL, Schonfeld SE. Gypsum casts as a potential source of microbial cross-contamination. J Prosthet Dent 1983;49:210-211.

2. Anusavice KJ. Phillip's science of dental materials. 10th ed. Philadelphia: WB Saunders Company; 1996.

3. Rutala WA, Weber DJ. Disinfection of endoscopes: review of new chemical sterilants used for high-level disinfection. Infect. Control Hosp Epidemiol 1999;20:69-76.

4. Cleaning and disinfection of equipment for gastrointestinal endoscopy. Report of a working party of the British Society of Gastroenterology Endoscopy Comittee. GUT 1998;42:585-593.
5. Rutala WA. Clinical effectiveness of low-temperature sterilization technologies. Infect Control Hosp Epidemiol 1998;19:798-804.

6. ISO 1567: Dentistry. Denture base polymers. Geneva, Switzerland: International Organization for Standardization; 2001. 32 p.

7. Andrés MT, Tejerina JM, Fierro JF. Reliability of biological indicators in a mail-return sterilization-monitoring service: a review of 3 years. Quintessence Int 1995;26:865-870.

8. Pavan S, Arioli Filho JN, Dos Santos PH, Mollo Fde A Jr. Effect of microwave treatments on dimensional accuracy of maxillary acrylic resin denture base. Braz Dent J 2005;16:119-123.

Accepted May 30, 2005 